\title{
Interaktywny Formularz Oświadczeń Majątkowych jako wielozadaniowe narzędzie wspierające przygotowanie i obieg oświadczeń o stanie majątkowym
}

\author{
Interactive Property Statement Form as a multi-purpose tool to \\ support the preparation and flow of property statements
}

\begin{abstract}
Streszczenie:
W pracy zaprezentowano desktopową aplikację wspierającą sporządzanie i obieg oświadczeń o stanie majątkowym. Program przeznaczony jest dla osób zobowiązanych do składania oświadczeń. Intuicyjne i ergonomiczne formularze wspierane są przez zbiory podpowiedzi i komentarzy. Podczas wypełniania oświadczenia można importować dane z poprzednio wprowadzonych dokumentów. Dodatkowo zastosowano kodowanie danych na wydruku w postaci QR kodów, które wykorzystywane są podczas rejestracji i digitalizacji dokumentów.
\end{abstract}

Słowa kluczowe: oświadczenie majątkowe, formularz, przygotowanie oświadczenia, obieg dokumentu, qr kod

\begin{abstract}
:
The article presents a desktop application supporting the preparation and flow of property declarations. The program is designed for people obliged to submit declarations. Intuitive and ergonomic forms are supported by collections of tips and comments. User can import data from the previously entered documents. The program is coding the data by QR codes. They are used during registering and digitizing documents.
\end{abstract}

Keywords: Property statement, form, statement preparation, document flow, qr code 
Radosław Woźniak - Interaktywny Formularz Oświadczeń...

\section{Wprowadzenie}

Celem aplikacji jest przeprowadzenie krok po kroku użytkownika przez proces sporządzenia i przygotowania oświadczenia o stanie majątkowym. Program zawiera obszerny system pomocy w formie podpowiedzi i komentarzy wyjaśniających poszczególne zapisy oświadczenia majątkowego i przedstawiających interpretacje przepisów prawa. Pozwala to na zapoznanie się z praktycznym i prawnym aspektem obowiązku składania oświadczenia. Narzędzie pomaga w wydrukowaniu dokumentu wraz z nadrukiem zawierającym zakodowane dane w formie QR kodu, który jest wykorzystywany w późniejszym etapie ewidencji i archiwizacji dokumentów. Dodatkowym atutem jest przechowywanie wprowadzonych danych w celu zaimportowania ich przy kolejnych okazjach wypełniania stosownych dokumentów.

Aplikacja została przygotowana dla żołnierzy zawodowych, ale jest również przeznaczona dla innych osób zobowiązanych do składania oświadczeń majątkowych. Mogą z niej korzystać m. in. pracownicy resortu obrony narodowej, pracownicy i funkcjonariusze innych służb, sędziowie, prokuratorzy, samorządowcy i parlamentarzyści.

Projekt związany jest ściśle z obszarem polityki obronnej i bezpieczeństwa państwa ${ }^{1}$ na płaszczyźnie antykorupcyjnej i prawnej. Aplikacja może stać się jednym z elementów zintegrowanego Systemu Bezpieczeństwa Narodowego jako pierwsze ogniwo wielozakresowego systemu antykorupcyjnego w postaci źródła danych ustrukturowanego modelu oraz narzędzia wspierającego przygotowanie i obieg dokumentów. Tak przygotowane dane pozwalają na zastosowanie wielu mechanizmów z zakresu analizy ekonomicznej, behawioralnej, prognozowania lub nawet sztucznej inteligencji w celu pogłębienia stanu wiedzy i wyciąganiu stosownych wniosków z oświadczeń o stanie majątkowym. Opracowane rozwiązanie jest wynikiem przeanalizowania problemów ze strony instytucji przetwarzających oświadczenia ma-

\footnotetext{
${ }^{1}$ Decyzja nr 4/NSzW Ministra Obrony Narodowej z dnia 22.02.2013 r. w sprawie wprowadzania do użytku służbowego w resorcie obrony narodowej dokumentu „Priorytety kierunku badań w resorcie obrony narodowej na lata 2013-2022".
} 
jątkowe oraz osób zobowiązanych do składania deklaracji. Są to m. in. procesy polegające na ewidencji, archiwizacji, monitorowaniu, sprawozdawczości i analizie oświadczeń o stanie majątkowym, a także na rozpoznaniu problemów spotykanych podczas wypełniania deklaracji.

Do wykonania projektu zastosowano własny sprzęt komputerowy, oprogramowanie oraz umiejętności badawcze, projektowania i implementacji rozwiązania informatycznego. Do rozpowszechnienia rozwiązania wykorzystano serwis internetowy Żandarmerii Wojskowej: http://zw.wp.mil.pl, w zakładce Oświadczenia Majątkowe (patrz Rys. 1.); aplikacja jest do pobrania za darmo.

Rys. 1. Serwis internetowy Żandarmerii Wojskowej, który udostępnia aplikację Interaktywny Formularz Oświadczeń Majątkowych

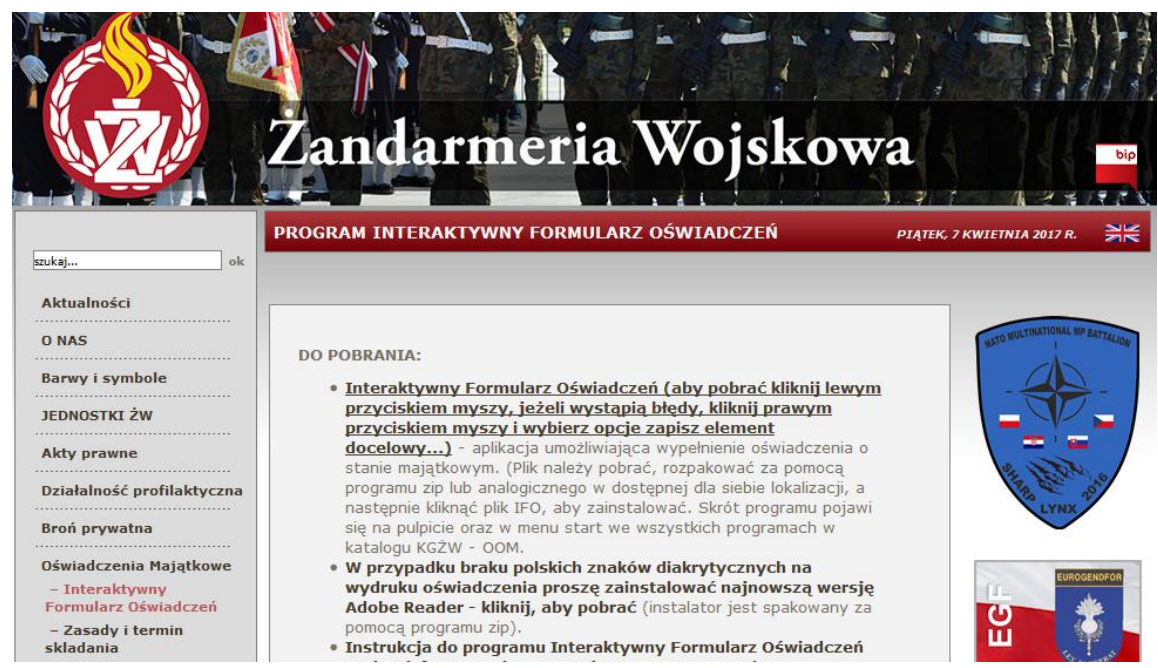

Źródło: Opracowanie własne na podstawie strony internetowej Żandarmerii Wojskowej.

W aspektach szkoleniowych i promocji działań Żandarmerii współpracowano z Wojskowym Wydawnictwem Specjalnym w Warszawie w celu wytłoczenia nośników CD z aplikacją Interaktywny Formularz Oświadczeń Majątkowych. Płyty CD takie jak na Rys. 2. z programem 
Radosław Woźniak - Interaktywny Formularz Oświadczeń...

rozdawane są podczas szkoleń przeprowadzanych przez Oddział Oświadczeń Majątkowych.

Rys. 2. Prezentacja nośnika z aplikacją Interaktywny Formularz Oświadczeń Majątkowych

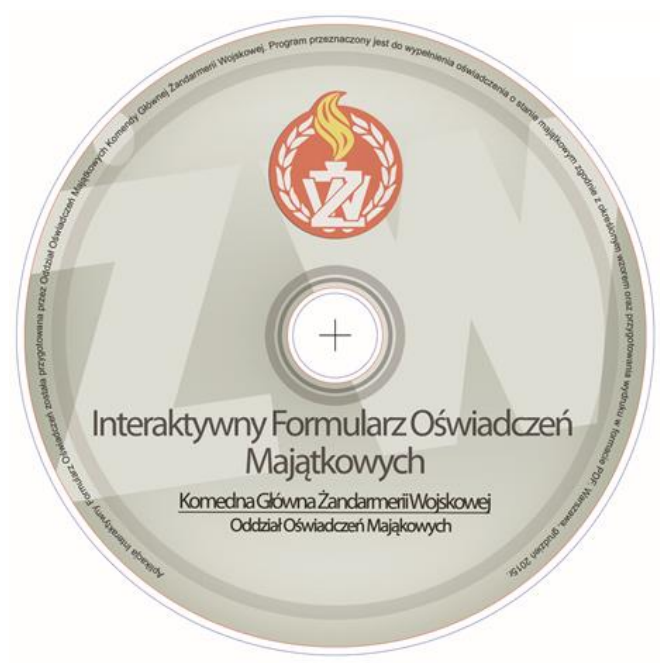

Źródło: Opracowanie własne.

Na dzień dzisiejszy z programu skorzystano ponad 10 tysięcy razy, co przyczyniło się w dużym stopniu do m. in. zmniejszenia liczby błędów popełnianych przez osoby składające oświadczenia, zwiększenia przejrzystości składanych dokumentów, propagowania informacji oraz podstaw prawnych na temat oświadczeń oraz znacznie przyspieszyło ewidencję i archiwizację dokumentów, dzięki wykorzystaniu autorskiego rozwiązania skanowania kodów z danymi zawierającymi składniki oświadczenia. 


\section{Modelowanie problemu}

Proces sporządzania i wysyłania dokumentu został zamodelowany na diagramie procesów biznesowych ${ }^{2}$ przedstawionym na Rys. 3. poniżej. Jest to zbiór czynności wykonywanych przez osoby, które zamierzają wypełnić, a następnie wysłać oświadczenie.

Rys. 3. Proces sporządzania i wysyłania dokumentu

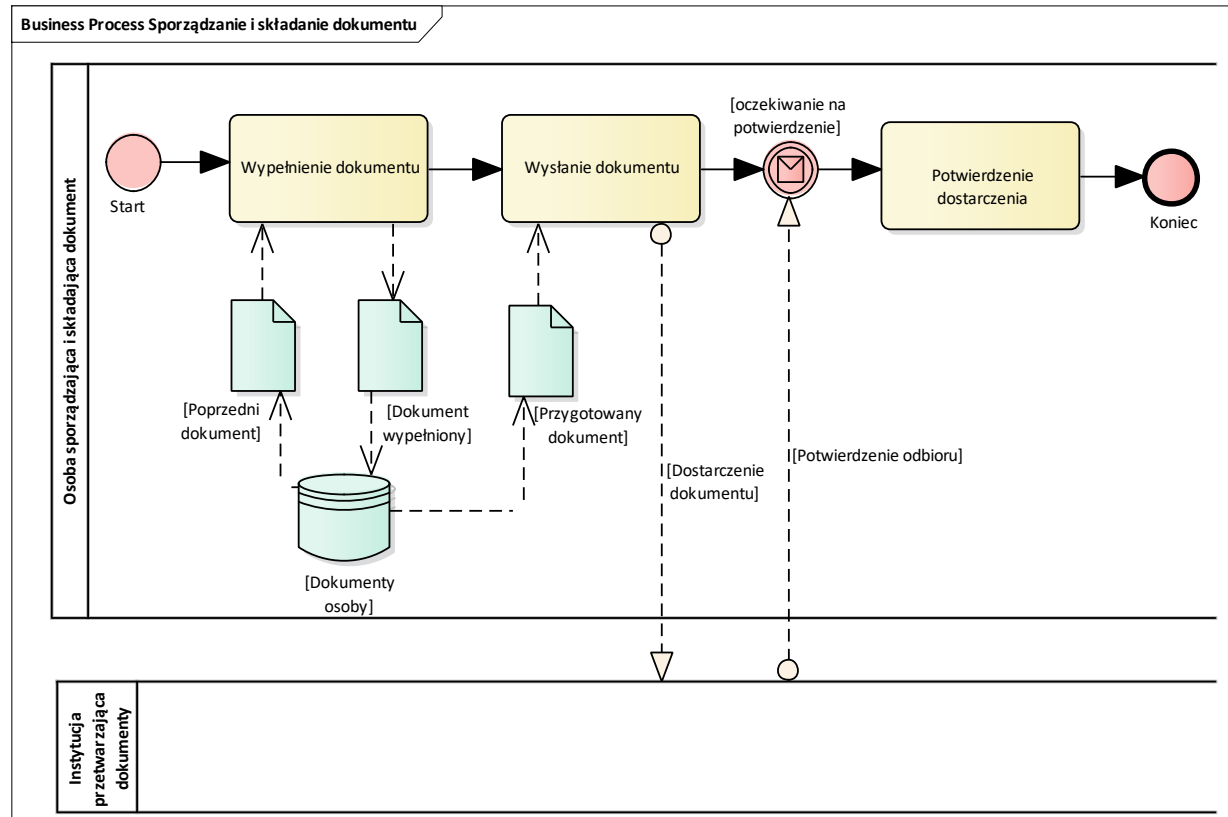

Źródło: opracowanie własne.

Podczas wypełniania dokumentu można zaimportować dane z poprzednich oświadczeń, m. in. dane osobowe swoje i małżonka, informacje na temat nieruchomości lub innych składników majątku. Następnie, przygotowany dokument należy wysłać do docelowej instytu-

2 S. Wrycza, B. Marcinkowski, Język inżynierii systemów SysML. Architektura i Zastosowania. Profile 2.x w praktyce, Warszawa 2013. 
Radosław Woźniak - Interaktywny Formularz Oświadczeń...

cji. W przypadku żołnierzy zawodowych jest to Żandarmeria Wojskowa. Wysłanie dokumentu na dzień dzisiejszy musi odbywać się drogą pocztową. W przyszłości istnieje możliwość wykorzystania informatycznych sposobów na dostarczenie dokumentów np. dzięki wykorzystaniu cyfrowego podpisu, platformy ePUAP (Elektroniczna Platforma Usług Administracji Publicznej), szyfrowania i UPO (Urzędowego Potwierdzenia Odbioru).

Proces przyjmowania i rejestrowania dokumentów został zamodelowany na diagramie procesów biznesowych przedstawionym na Rys. 4. Jest to zbiór czynności wykonywanych przez pracowników instytucji przetwarzającej dokumenty w celu realizacji określonych zadań, np. dla Żandarmerii Wojskowej jest to ustawowe zadanie polegające m. in. na gromadzeniu i przeprowadzaniu analiz oświadczeń o stanie majątkowym.

Rys. 4. Proces Przyjmowania i rejestracji dokumentów

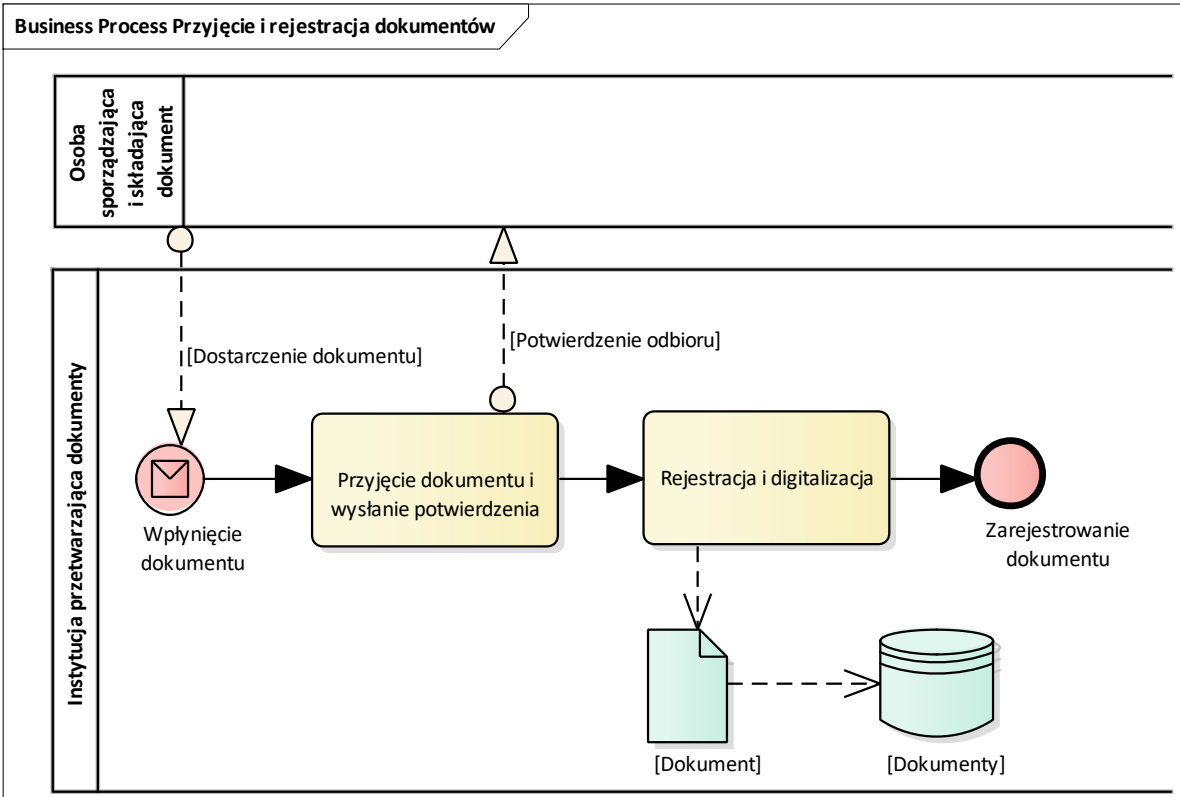

Źródło: opracowanie własne. 
Po wpłynięciu dokumentów instytucja dokonuje czynności związanych z ewidencją i archiwizacją oświadczeń, które polegają m. in. digitalizacji dokumentów w celu przeprowadzenia zadań analitycznych i statystycznych.

\section{Zastosowane rozwiązania}

Tak jak wspomniano wcześniej na wydrukach znajdują się charakterystyczne kody kreskowe. Na Rys. 5 znajduje się przykładowa reprezentacja graficzna QR kodu, zawierająca 17 wersów wiersza Juliana Tuwima pt. „Do prostego człowieka”.

Rys. 5. Ciąg 504 znaków w postaci QR kodu

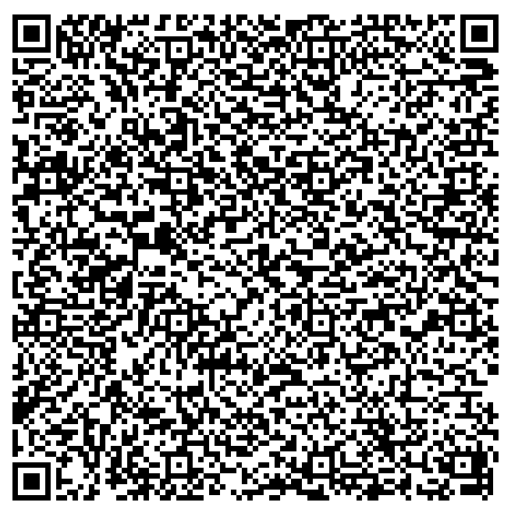

Źródło: opracowanie własne.

Kod QR (ang. Quick Reponse Code) to dwuwymiarowy, kwadratowy obrazek, zwany też kodem kreskowym, który pozwala na zapisanie danych w sposób graficzny. Zależnie od rozmiaru, może zawierać do 4296 znaków alfanumerycznych. Kod opracowany został przez japońską firmę w $1994 \mathrm{roku}^{3}$. Organizacja ISO w 2000 roku zatwierdziła dwuwymiarowy kod jako międzynarodowy standard ISO/IEC18004.

\footnotetext{
${ }^{3}$ QRCode, http://www.qrcode.com/en, [dostęp: 19.04.2017].
} 
Radosław Woźniak - Interaktywny Formularz Oświadczeń...

Elementem podstawowym QR kodu jest moduł, który przybiera czarny (ciemny) lub biały (jasny) kolor. Odpowiednia ich kombinacja tworzy słowa kodowe, które odpowiadają za poszczególne znaki. Rozmiar zewnętrzny zależy od ilości zapisanych danych, określonej wersji kodu oraz zastosowanego mechanizmu korekcji błędów. Kod jest wykorzystywany w przewodnikach, oznaczeniach produktów, wspieraniu przelewów bankowych, wizytówkach, systemach dostępu np. na konferencjach, czy też kodowania danych np. w dokumentach.

Rys. 1. Sposoby ewidencjonowania i archiwizacji dokumentów

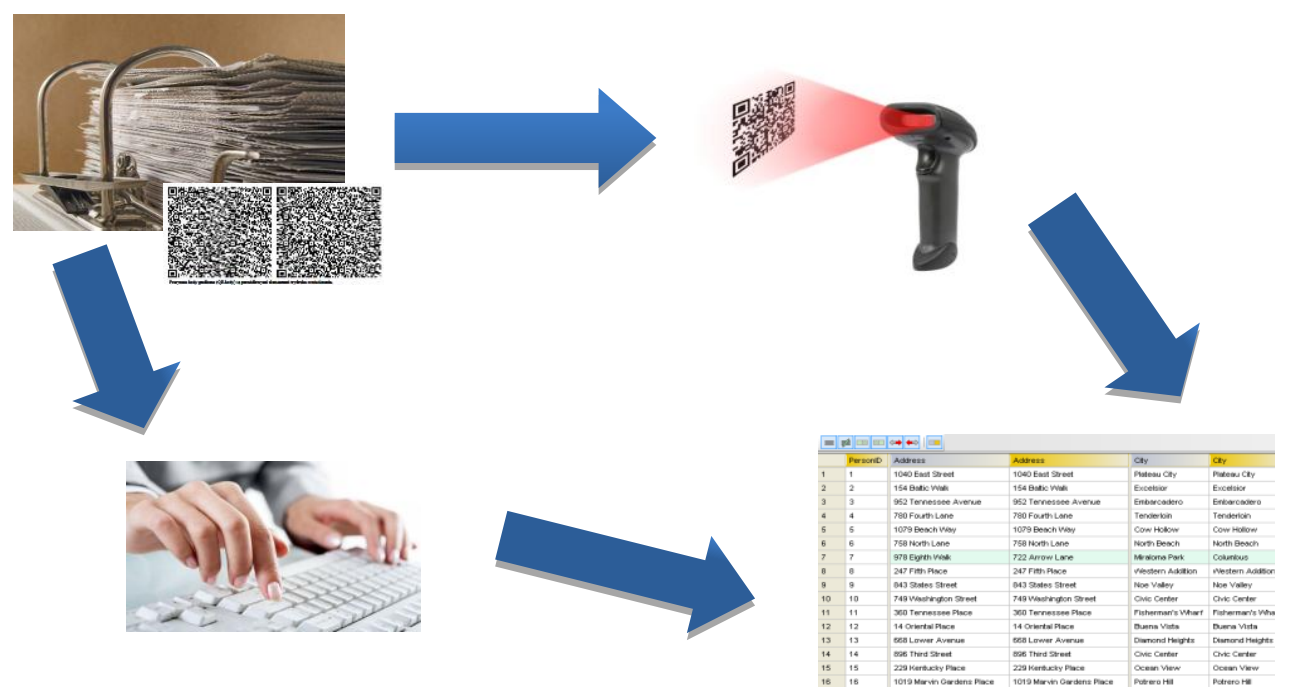

Źródło: opracowanie własne na podstawie artykułu4.

Zastosowanie QR kodów pozwala na przyspieszenie procesu digitalizacji dokumentów. Dane zakodowane w kodach kwadratowych są przesyłane do komputera za pomocą czytników. Na Rys. 6 przedstawiono sposoby ewidencjonowania i archiwizacji dokumentów. Następnie aplikacja dekoduje oraz utrwala dane. Proces ten trwa

${ }^{4}$ T. Piekarski, J. Korpusik, R. Woźniak, Funkcjonowanie oświadczeń o stanie majątkowym w Siłach Zbrojnych RP - teraźniejszość i kierunki rozwoju, II Konferencja Antykorupcyjna. „Realizacja działań antykorupcyjnych w resorcie obrony narodowej”, Komenda Główna Żandarmerii Wojskowej, Warszawa 2017. 
kilkanaście razy szybciej od standardowego rozwiązania polegającego na przepisywaniu danych zawartych w dokumentach. W ten sposób możliwe jest uniknięcie błędów powstających podczas przepisywania spowodowanych $\mathrm{m}$. in. przemęczeniem pracownika.

Warto wspomnieć o informatycznej budowie narzędzia. Wielozadaniowa platforma wzoruje się na wzorcu architektonicznym MVC (Model - View - Controller) ${ }^{5} \mathrm{z}$ wykorzystaniem zalet wzorca MVVM (Model - View - ViewModel). MVC jest złożonym wzorcem, często wykorzystywanym w aplikacjach sieciowych umożliwiającym pełną kontrolę nad zachowaniem aplikacji. Warstwa modelu jest odpowiedzialna za dane oraz logikę biznesową, czyli funkcjonalności. Warstwa widoku to wizualna cześć aplikacji odpowiedzialna za komunikację $\mathrm{z}$ użytkownikiem. Kontroler zawiera zachowania odpowiedzialne za zdarzenia i interakcje pomiędzy warstwami modelu i widoku. Wzorzec MVVM jest rozwiązaniem wykorzystywanym w aplikacja desktopowych. W tym przypadku ViewModel nie tylko odpowiada za komunikację pomiędzy warstwami widoku i modelu, ale również przejmuje rolę części logiki biznesowej.

Wydzielenie dodatkowych warstw, m.in. dla logiki biznesowej pozwala na rozszerzenie możliwości platformy, zwiększa jej testowalność, wspiera współpracę programistów w zespołach projektowych, zwiększa poziom kontroli nad zachowaniem aplikacji. Znaczącą zaletą odseparowania warstw jest możliwość posiadania wielu niezależnych widoków dlatego samego modelu. Natomiast minusem jest zwiększenie złożoności kodu programu.

\section{Wizualizacja aplikacji}

Poniżej przedstawiono zrzuty ekranu uruchomionego programu dla przykładowej osoby. Wydruk oświadczenia prezentowany jest

\footnotetext{
5 ASP.NET MVC - omówienie, https://msdn.microsoft.com/pl-pl/library/dd3814 12 (v=vs.108).aspx, [dostęp: 20.04.2017].
} 


\section{Radosław Woźniak - Interaktywny Formularz Oświadczeń...}

w formacie PDF i zawiera dodatkowo pola z zakodowanymi danymi w postaci QR kodów.

Rys. 2. Okno aplikacji przedstawiające formularz uzupełniania danych osobowych

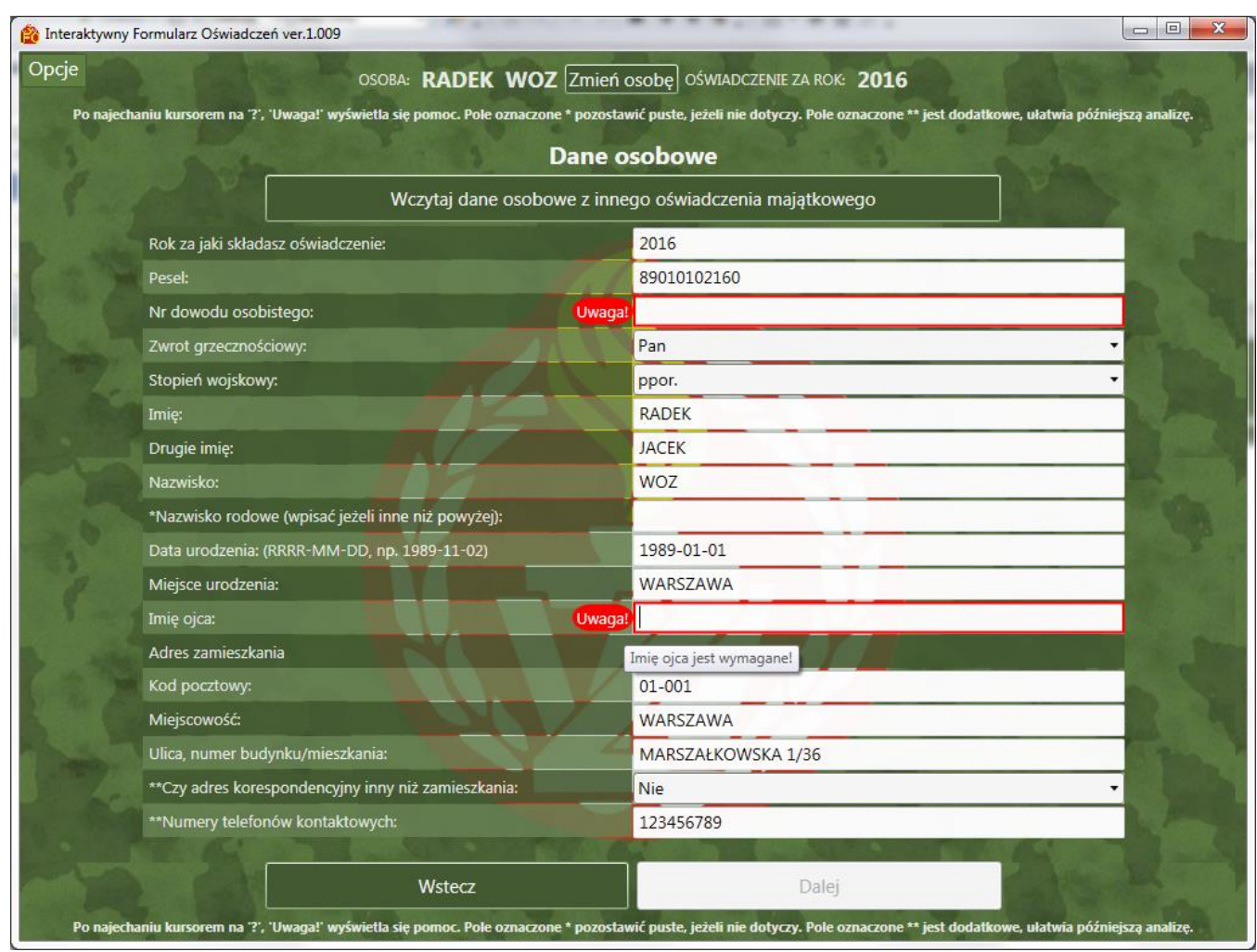

Źródło: opracowanie własne. 
Rys. 3. Fragment formularza uzupełniania zasobów pieniężnych wraz z podpowiedzią

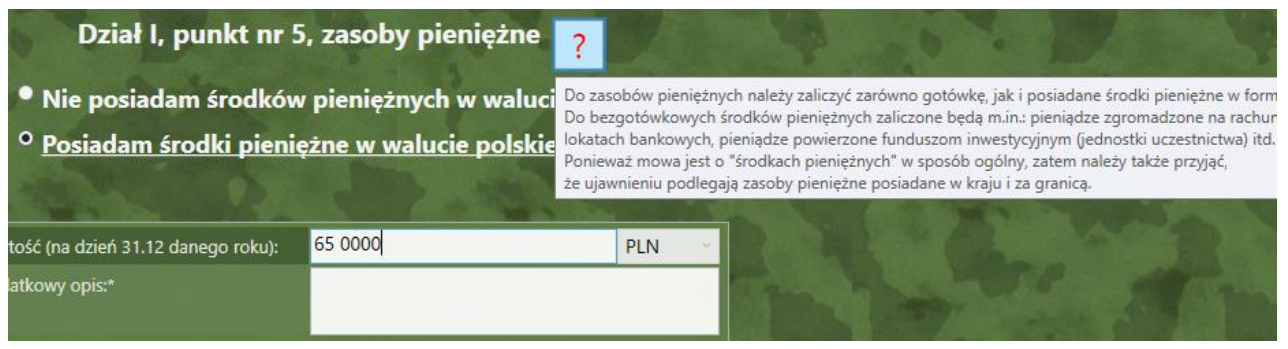

Źródło: opracowanie własne.

Rys. 4. Fragment formularza uzupełniania składników mienia ruchomego $\mathrm{z}$ uwidocznioną listą wyboru rodzaju mienia

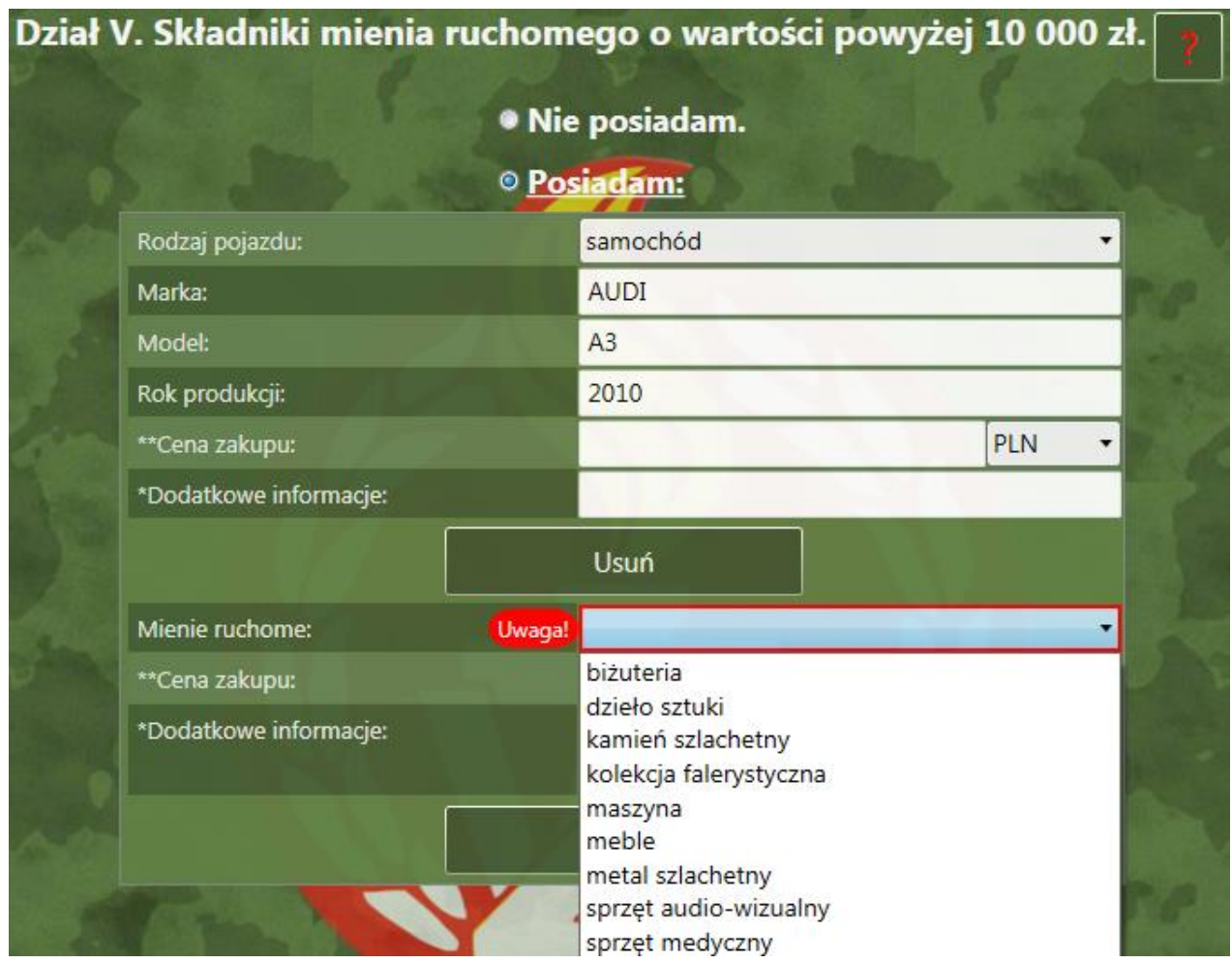

Źródło: opracowanie własne. 


\section{Radosław Woźniak - Interaktywny Formularz Oświadczeń...}

Rys. 5. Fragment ostatniego okna umożliwiającego zapis dokumentu oraz jego wydruk

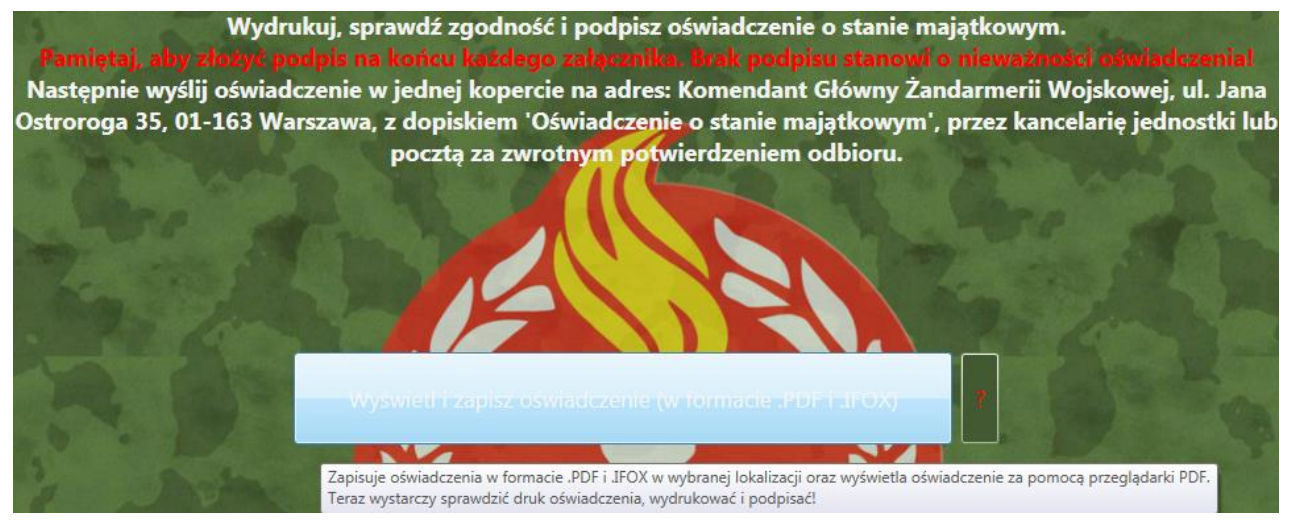

Źródło: opracowanie własne. 
Rys. 6. Pierwsza strona załącznika nr 3 oświadczenia o stanie majątkowym wraz z widocznymi QR kodami

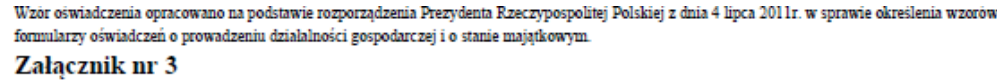

\section{Oświadczenie o stanie majątkowym}

\section{$\mathrm{Ja}$, niżej podpisany, ppor. RADEK JACEK WOZ, PESEL: 89010102160 , nr dowodu osobistego: ABC123456, urodzony 1989-01-01, w WARSZAWA, zatrudniony jako PROGRAMISTA w jw KOMENDA GLÓWNA ŻANDARMERI WOJSKOWEJ, \\ zamieszkaly: 01-001 WARSZAWA, MARSZALKOWSKA 1/36, tel. do kontaktu 123456789}

po zapoznaniu się z przepisami ustawy z dnia 21 sierpnia 1997 r. o ograniczeniu prowadzenia dzialalności gospodarczej przez osoby pelniące funkcje publiczne (Dz. U. z 2006 r. Nr 216, poz. 1584, z późn. zm.), zgodnie z art.10 tej ustawy oświadczam, że posiadam wchodzạce w sklad wspólności ustawowej lub stanowiące mój majątek odrẹbny:

1. Domy: Nie posiadam domu.

2. Mieszkania:

- Mieszkanie o powierzchni: 55 M2, adres: 01-001 WARSZAWA, MARSZALKOWSKA 1/36, tytul prawny: wlasność, sposób wejścia w posiadanie: nabycie, nr aktu notarialnego: REPERT 12345/2015, dodatkowa informacja: NA LICYTACJI KOMORNICZEJ

- Mieszkanie opowierzchni: 44, adres: 01-424 WARSZAWA, PRZY LASKU 8/2, tytul prawny: kwatera/mieszkanie slużbowe, sposób wejścia w posiadanie: decyzja Dyrektora WAM/AMW

3. Gospodarstwa rolne: Nie posiadam gospodarstwa rolnego.

4. Inne nieruchomości:

- Inna nieruchomość, rodzaj nieruchomości: garaż, o powierzchni: 18 M2, adres: 01-001 WARSZAWA, MARSZALKOWSKA 1, tytul prawny: najem

5. Zasoby pieniężne:

- środki pieniężne w walucie polskiej: 8000 PLN, opis: KONTO OSOBISTE I GOTÓWKA

- środki pieniężne w walucie polskiej: 123000 PLN, opis: KONTO OSZCZEDNOŚCIOWE I LOKATY

- środki pienięzine w walucie obcej: 5000 EUR, opis: LOKATA

- środki pieniężne w walucie obcej: $1000 \mathrm{GBP}$

- papiery wartościowe: Nie posiadam papierów wartościowych

\section{II}

Nabylem (nabyla moja malżonka) mienie od Skarbu Państwa, innej państwowej osoby prawnej, jednostek samorzadu terytorialnego, ich związów lub komunalnej osoby prawnej, które podlegalo zbyciu $w$ drodze przetargu:

Tak. Nabylem nastẹpujace mienie:

- Rodzaj: mieszkanie, o powierzchni: 55 M2, adres: 01-001 WARSZAWA, MARSZALKOWSKA 1/36, tytul prawny: wlasność, sposób wejścia w posiadanie: nabycie, akt notarialny: REPERT 12345/2015

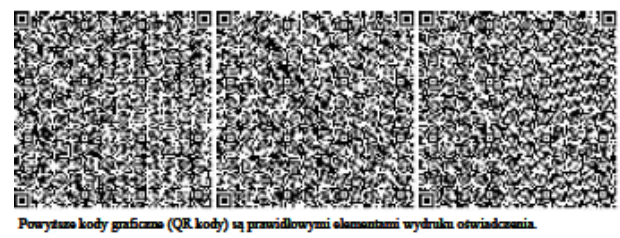

Źródło: opracowanie własne. 
Radosław Woźniak - Interaktywny Formularz Oświadczeń...

\section{Analiza SWOT}

Tabela 1. Mocne i słabe strony oraz szanse i zagrożenia dla rozwiązania

\begin{tabular}{|c|c|}
\hline ZAKRES & OPIS \\
\hline $\begin{array}{l}\text { Mocne } \\
\text { strony }\end{array}$ & $\begin{array}{l}\text { - Brak poprzedniego zinformatyzowanego rozwiązania. } \\
\text { - Ergonomiczny interfejs aplikacji, który prowadzi użytkownika } \\
\text { krok po kroku przez proces sporządzania dokumentu. } \\
\text { - Proste i czytelne formularze ułatwiające opisanie składników ma- } \\
\text { jątku. } \\
\text { - Podsystem komentarzy i podpowiedzi wyjaśniających szereg pojęć } \\
\text { z zakresu finansów, mienia, dochodów itp. } \\
\text { - Możliwość dodawania wielu składników majątku tego samego } \\
\text { rodzaju, a nie jak do dotychczas ustaloną z góry liczbę } 1 \text {. } \\
\text { - Przejrzysty i skompresowany wydruk dokumentu zajmujący po- } \\
\text { nad połowę mniej miejsca niż podstawowy wzór. } \\
\text { - Wykorzystanie QR kodów, w celu kodowania informacji w postaci } \\
\text { kodów kreskowych na wydruku. Jest to wykorzystywane podczas } \\
\text { skanowania dokumentów i wprowadzania składników majątku. } \\
\text { - Możliwość importowania i korzystania z wcześniej wprowadzo- } \\
\text { nych danych w celu szybszego wypełnienie dokumentu. } \\
\text { - Szybka i prosta instalacja z nośników CD lub z Internetu. } \\
\text { - Nie ma potrzeby przeprowadzania szkolenia z korzystania z apli- } \\
\text { kacji. } \\
\text { - Oprogramowanie dostępne na systemy operacyjne Windows (XP, } \\
\text { 7, 8, 8.1., 10). }\end{array}$ \\
\hline $\begin{array}{l}\text { Słabe } \\
\text { strony }\end{array}$ & $\begin{array}{l}\text { - Oprogramowanie nie jest dostępne na innych systemach operacyj- } \\
\text { nych niż z rodziny Windows. }\end{array}$ \\
\hline Szanse & $\begin{array}{l}\text { - Zastosowany wzór elastycznych formularzy oraz podsystemu pod- } \\
\text { powiedzi pozwala użytkownikom na bezproblemowe i jednoznacz- } \\
\text { ne wypełnienie dokumentu, bez potrzeby dodawania komentarzy } \\
\text { na marginesach lub dołączania dodatkowych stron. } \\
\text { - Skanowanie kodów QR powala na kilkukrotnie szybsze zarejestro- } \\
\text { wanie dokumentu oraz digitalizację składników majątku w Syste- } \\
\text { mie Informatycznym. Pozwala na uniknięcie błędów powstałych } \\
\text { podczas przepisywania dokumentów do Systemu. } \\
\text { - Możliwość korzystania przez wszystkich żołnierzy zobowiązanych } \\
\text { do składania oświadczeń majątkowych. }\end{array}$ \\
\hline
\end{tabular}




\begin{tabular}{|c|c|}
\hline & $\begin{array}{l}\text { - Możliwość korzystania przez wszystkie osoby (m. in. pracowników } \\
\text { i funkcjonariuszy innych służb, sędziów, prokuratorów, samorzą- } \\
\text { dowców, parlamentarzystów) zobowiązane do składania oświad- } \\
\text { czeń majątkowych. } \\
\text { - Bardzo dobre opinie osób korzystających z aplikacji. }\end{array}$ \\
\hline Zagro & $\begin{array}{l}\text { - Możliwe problemy z obsługą aplikacji przez osoby stroniące od } \\
\text { komputerów. }\end{array}$ \\
\hline
\end{tabular}

Źródło: opracowanie własne.

\section{Określenie biegunowości i wnioski z analizy SWOT}

Z powyższej tabeli można zauważyć pozytywny kierunek wykorzystywania i rozwoju przedstawionego rozwiązania. Liczba mocnych stron i szans w diametralnym stopniu przewyższa słabe strony i zagrożenia. Jest to istotna przesłanka dalszego korzystania z przedstawionego rozwiązania.

Poprzednie rozwiązanie pozwalało tylko na ręczne wypełnianie dokumentu. W związku z tym oraz wymienionymi w tabeli zaletami można zauważyć, że proponowane rozwiązanie przedstawia nowe, innowacyjne podejście do problemu sporządzania oświadczeń o stanie majątkowym. Ponadto przedstawione rozwiązanie nie wymaga wycofania poprzedniego rozwiązania.

\section{Podsumowanie}

Przedstawione narzędzie w sposób ergonomiczny pozwala na komunikację między człowiekiem a komputerem. Aplikacja $\mathrm{z}$ jednej strony ułatwia w sposób czytelny wypełnienie oświadczenia o stanie majątkowym, tj. bez często popełnianych błędów oraz zachowaniem wszystkich wymaganych elementów dokumentu. Z drugiej strony wykorzystanie funkcji skanowania kodów dwuwymiarowych dla pracowników oddziału znacznie przyspiesza procedurę rejestracji i digitalizacji oświadczeń poprzez wyeliminowanie konieczności przepisywania danych. 
Radosław Woźniak - Interaktywny Formularz Oświadczeń...

Zastosowane rozwiązanie pozwala na wdrożenie mechanizmów i algorytmów analizy oświadczeń majątkowych pod względem ekonomicznym oraz behawioralnym z wykorzystaniem sztucznej inteligencji i elementów symulacyjnych w celu wykrycia nieprawidłowości, a także nadużyć finansowych.

Warto zauważyć, że na dzień dzisiejszy brak jest kompleksowych narzędzi zawierających przedstawione rozwiązanie. Dlatego warto rozszerzyć możliwości tej wielozadaniowej platformy.

\section{Bibliografia:}

ASP.NET MVC - omówienie, https://msdn.microsoft.com/pl-pl/library/dd38 1412(v=vs.108).aspx.

Decyzja nr 4/NSzW Ministra Obrony Narodowej z dnia 22.02.2013 r. w sprawie wprowadzania do użytku służbowego $w$ resorcie obrony narodowej dokumentu „Priorytety kierunku badań w resorcie obrony narodowej na lata 2013-2022".

Piekarski T., Korpusik J., Woźniak R., Funkcjonowanie oświadczeń o stanie majątkowym w Siłach Zbrojnych RP - teraźniejszość i kierunki rozwoju, II Konferencja Antykorupcyjna. „Realizacja działań antykorupcyjnych w resorcie obrony narodowej”, Komenda Główna Żandarmerii Wojskowej, Warszawa 2017.

QRCode, http://www.qrcode.com/en.

Wrycza S., Marcinkowski B., Język inżynierii systemów SysML. Architektura i Zastosowania. Profile 2.x w praktyce, Helion, Warszawa 2013. 